\title{
EFFECTS OF DISTILLERY EFFLUENT ON SOME AGRICULTURAL CROPS: A CASE OF ENVIRONMENTAL INJUSTICE TO LOCAL FARMERS IN KHAJURA VDC, BANKE
}

\author{
Rita Ale*, P. K. Jha** and N. Belbase*** \\ * Student Bank Street Graduate School of Education, New York, USA. \\ **Central Department of Botany, Tribhuvan University, Kritipur, Kathmandu, Nepal. \\ ***Forum for Justice, Kathmandu, Nepal.
}

\begin{abstract}
Effluent discharged from the Karnali distillery Pvt. Ltd was analyzed to measure its effect on agricultural crops and environmental justice to the concerned people. Physico-chemical parameters like pH, temperature, Dissolved Oxygen (DO), Biochemical Oxygen Demand (BOD), Chemical Oxygen Demand (COD), Total Suspended Particles (TSS), Nitrogen (N), Phosphorus (P), Potassium (K) and some heavy metals such as Iron (Fe), Manganese (Mn), Cadmium (Cd), Lead (Pb), Zinc (Zn), and Copper $(\mathrm{Cu})$ were analyzed and found most of the physico-chemical parameters were above the toxic level set by Nepal Bureau Standard. The analysis of physico-chemical parameters of the soil irrigated with effluent polluted water revealed appreciable increase in the soil nutrients (Organic Matter, N, P, K) along with the increase of toxic heavy metals such as Fe, Cd, Mn and Pb in the soil which has decreased annual crop productivity by around 40 percent. Similarly the effect of the effluent on seed germination, seedling growth, fresh weight and dry weight of seedlings of two test crops (Oryza sativa and Triticum aestivum) were also analyzed and found the effect varied in different concentration of treatment. Higher concentrations (10\%, 25\%) were found completely inhibitory where as lower concentrations $(1 \%, 5 \%)$ were found stimulatory and reached up to the level of control. The present study showed that the distillery effluent was highly loaded with organic pollutants along with harmful heavy metals which showed significant effect on soil quality and the crop productivity which caused environmental injustice to the local people in terms of loss of crop productivity and environmental hazards.
\end{abstract}

Key words: Heavy metals; Effluent; Pollution; Soil chemistry; Environmental justice.

\section{INTRODUCTION}

Distillery industries plays major role in the environment pollution. The organic effluent (spentwash) discharged by such industries is one of the most complex, troublesome and strongest organic industrial effluent having extremely high BOD and COD values (Nagraj et al., 2006). Many industries in Nepal discharge their effluent directly or indirectly into land or small channel leading to the nearby river due to which water quality of most of the rivers and streams get degraded. Such water is not safe for human being, livestock and irrigation. Industrial effluents may cause enrichment of heavy metals in the top soil if it is regularly applied to soil in excessive amount and ultimately may reduce yield and impure the quality of crops (Singh et al., 1985). However, many farmers in urban areas are compelled to use polluted river water or direct industrial effluent to irrigate their cropland due to the absence of better alternatives (Ghimire, 1994).

A clean, healthy and safe environment is a fundamental right of all human beings. Concepts of environmental justice strongly address this fundamental right. According to U.S. EPA(2000), environmental justice is the fair treatment to people of all races, culture and income levels with respect to the development, implementation and enforcement of environmental laws, regulations and policies. The principle of envi- ronmental justice demands that public policy be based on mutual respect and justice for all people from any form of discrimination or bias and principle number 6 demands the cessation of production of all toxins, hazardous wastes and radioactive materials and that all parts and current producers be held strictly accountable to the people for detoxification and the containment at the point of production. It can be understood that principles of environmental justice focus on the right of all people to live in clean and healthy environment.

The interim constitution of Nepal 2007, guarantees the right to every person to live in a clean environment. This provision has potential for far reaching effects in addressing the disproportionate distribution of environmental hazards in urban areas with respect to marginalized groups and poor communities. (Belbase and Thapa, 2007). However, in Nepal most of the industries have been established without or with low quality waste water or effluent treatment plants. Such industries have brought adverse impact on the local environment of the industrial area. Mostly the farmers and low income resource people get affected by such industries. Beside these, there is not such distinct rules and regulation of compensation system which result poor people bear great loss. Hence, this study was undertaken to assess the injustice on concerned people due to the distillery effluent.

Author for Correspondence: P. K. Jha, Central Department of Botany, T.U. Kritipur, Kathmandu, Nepal. Email: pkjhaprof@gmail.com 


\section{MATERIALS AND METHODS}

\section{Sampling of the Industrial Effluent, Stream Water and Soil}

For the present investigation, the effluent of the Karnali Distillery Pvt. Ltd. Khajura, Nepalgunj was collected in June 2006 when the factory was running at full capacity. Samples were collected in plastic bottles of one litre. For the analysis of heavy metals, effluent samples were acidified with $\mathrm{HNO}_{3}(\mathrm{pH}<2)$ at the time of collection following Trivedy and Goel (1986). Soil samples were collected from two sites i.e. crop fields irrigated with effluent mixed and non-effluent stream water in June and October 2006. About 500g of two soil samples from each site were collected in a zipper bag. Parameters of effluent such as temperature, $\mathrm{pH}$, total suspended particles, dissolved oxygen, chemical oxygen demand, biological oxygen demand, nitrogen, phosphorus, and potassium, heavy metals such as lead (Pb), Zinc ( $\mathrm{Zn})$, Cupper (Cu), Manganese (Mn), Iron (Fe) and Cadmium (Cd) were analysed in the laboratory of Nepal Bureau of Standards and Measures, Balaju, Kathmandu. The germination experiment was carried out in the laboratory of Central Department of Botany, Tribhuvan University. Soil Analysis was done in Soil Science Division, Nepal Agricultural Research Council, Khumaltar, Lalitpur and Regional Soil Experiment Laboratory, Khajura, Nepalganj, Banke.

\section{Method of Effluent and Soil Test}

All the analytical processes of effluent and heavy metals of soil were carried out according to the standard method for the examination of water and waste water (APHA, 1998). Soil samples were analyzed for total Nitrogen, Phosphorus and Potassium following Bajwa et al. (1997) where as Organic matter of soil was determined by using Walkley and Black's rapid titration method.

\section{Germination Experiment}

The seeds of paddy (Oryza sativa), var. 'Barse 3004' and wheat (Triticum aestivum) var. 'Bhrikuti' were used.The germination tests were carried out in Petri dishes at $26 \pm 2^{\circ} \mathrm{C}$. Ten seeds were sown at equidistant in sterilized $10 \mathrm{~cm}$ Petri dishes lined with Whatman filter paper. Ten replicas were used for each treatment. Then $5 \mathrm{ml}$ of filtered undiluted (100\%) or diluted (1\%, 5\%, $10 \%, 25 \%, 50 \%)$ effluent solutions were added to each Petri dish. A control experiment was carried out using distilled water. $1 \mathrm{ml}$ of effluent was added at an interval of three days to keep the level of effluent constant. Seed germination was observed at the interval of 24 hour for five days and the emergence of radicle upto $2 \mathrm{~mm}$ in length was considered as a criterion for germination following Street and Opik, 1976. Root and shoot length were measured on each fifth day interval. After 15 days, seedlings were taken out from each Petri dish and their respective root and shoot length were measured. Seedling components were separated into root and shoot and measured separately for their fresh weight. These seedling parts were dried in an oven for 48 hour at $75^{\circ} \mathrm{C}$ and their respective dry weight was taken. Analysis of variance is the major statistical tool used in the study for testing the statistical significance of the variance of mean at $\mathrm{P}=0.05$. Overall statistical analysis (F-test) of the present study was done in the SPSS (10.1).

\section{Interview with Local People}

Altogether twenty local farmers from site A (Irrigated with unpolluted stream water) and site B (Irrigated with effluent polluted stream water) were interviewed with the help of standard questionnaire by participatory rapid appraisal (PRA) method to know the effluent and environmental justice.

Table 1: Pysico-Chemical Characteristics of Effluent from Karnali Distillery Pvt. Ltd. and its Associated Stream Water.

\begin{tabular}{|c|c|c|c|c|c|}
\hline S.N. & Parameter & Unit & Concentrate & Dilute & Stream water without effluent \\
\hline 1. & Temperature & ${ }^{\circ} \mathrm{C}$ & 105 & 36 & 30 \\
\hline 2. & $\mathrm{pH}$ & - & 3.7 & 4.0 & 6.2 \\
\hline 3. & Total suspended solid & $\mathrm{mg} / \mathrm{l}$ & 32311 & 2033 & 450 \\
\hline 4. & Dissolved Oxygen (DO) & $\mathrm{mg} / \mathrm{l}$ & 0.36 & 2.9 & 5.2 \\
\hline 5. & Total Nitrogen & $\mathrm{mg} / \mathrm{l}$ & 465 & 335 & 12.2 \\
\hline 6. & Phosphate & $\mathrm{mg} / \mathrm{l}$ & 141.4 & 3.9 & 0.3 \\
\hline 7. & Potassium & $\mathrm{mg} / \mathrm{l}$ & 5440 & 1000 & 16.8 \\
\hline 8. & Biochemical Oxygen Demand & $\mathrm{mg} / \mathrm{l}$ & 47520 & 15450 & 105 \\
\hline \multirow[t]{2}{*}{9.} & Chemical Oxygen Demand & mg/l & 58400 & 32100 & 152 \\
\hline & Heavy Metals & & & & \\
\hline 1. & Iron (Fe) & mg/l & 115 & 102.4 & 4.7 \\
\hline 2. & Manganese (Mn) & $\mathrm{mg} / \mathrm{l}$ & 6.4 & 5.7 & 0.6 \\
\hline 3. & Lead (Pb) & $\mathrm{mg} / \mathrm{l}$ & 0.56 & 0.29 & 0.01 \\
\hline 4. & Copper (Cu) & $\mathrm{mg} / \mathrm{l}$ & 0.14 & 0.05 & 0.04 \\
\hline 5. & Zinc (Zn) & $\mathrm{mg} / \mathrm{l}$ & 3.1 & 1.21 & 0.06 \\
\hline 6. & Cadmium (Cd) & $\mathrm{mg} / \mathrm{l}$ & 7.5 & 5.2 & 0.31 \\
\hline
\end{tabular}


Table 2: Chemical Characteristics of Soil from Effluent Irrigated and Non-Irrigated Crop Field

\begin{tabular}{|c|c|c|c|c|c|c|c|c|}
\hline \multirow[b]{2}{*}{$\mathrm{SN}$} & \multirow[b]{2}{*}{ Parameter } & \multirow[b]{2}{*}{ Unit } & \multicolumn{2}{|c|}{ Before Monson } & \multicolumn{2}{|c|}{ After Monson } & \multicolumn{2}{|c|}{ Average } \\
\hline & & & Site A & Site B & Site A & Site B & Site A & Site B \\
\hline A. & General & & & & & & & \\
\hline 1. & $\mathrm{pH}$ & - & 7.5 & 6.7 & 7.0 & 6.2 & 7.2 & 6.4 \\
\hline 2. & Organic Matter & $\mathrm{mg} / \mathrm{l}$ & 0.51 & 3.13 & 0.54 & 5.04 & 0.52 & 4.07 \\
\hline 3. & Total Nitrogen & $\%$ & 0.09 & 0.16 & 0.11 & 0.19 & 0.10 & 0.17 \\
\hline 4. & $\mathrm{P}_{2} \mathrm{O}_{5}-\mathrm{P}$ & kg/ha & 71.8 & 228.4 & 96.0 & 137 & 83.9 & 182.7 \\
\hline 5. & $\mathrm{~K}_{2} \mathrm{O}-\mathrm{K}$ & $\mathrm{kg} / \mathrm{ha}$ & 307.7 & 940 & 110 & 240 & 208.8 & 590 \\
\hline B. & Heavy Metals & & & & & & & \\
\hline 1. & Iron $(\mathrm{Fe})$ & $\mathrm{mg} / \mathrm{l}$ & 18300 & 18875 & 14520 & 15100 & 16697 & 16700 \\
\hline 2. & Manganese (Mn) & $\mathrm{mg} / \mathrm{l}$ & 410 & 477 & 230 & 360 & 320 & 418.5 \\
\hline 3. & Copper (Cu) & $\mathrm{mg} / \mathrm{l}$ & 16 & 18 & 15 & 16 & 15.5 & 17 \\
\hline 4. & Zinc (Zn) & $\mathrm{mg} / \mathrm{l}$ & 45 & 32 & 40 & 28 & 42 & 30 \\
\hline 5. & Lead (Pb) & $\mathrm{mg} / \mathrm{l}$ & 10 & 18 & 12 & 15 & 11 & 16.5 \\
\hline 6. & Cadmium (Cd) & $\mathrm{mg} / \mathrm{l}$ & 28 & 41 & 25 & 40 & 26.5 & 40.5 \\
\hline
\end{tabular}

Note: Site A - Irrigated with non-effluent stream water. Site B - Irrigated with effluent mixed stream water.

\section{RESULTS AND DISCUSSION}

\section{Physico-Chemical Parameters of Effluent}

Effluent from the Karnali Distillery Pvt. Ltd., Khajura, Banke was dark brown in colour with strong odour. Comparatively almost all the parameters were found higher in concentrate and dilute effluent than in effluent non-mixed stream water.

The temperature of concentrate effluent of Karnali distillery was recorded $105^{\circ} \mathrm{C}$ where as that of dilute and the non-effluent stream water were recorded as $36^{\circ} \mathrm{C}$ and $30^{\circ} \mathrm{C}$ respectively. The effluent of Karnali distillery was highly acidic in nature with $\mathrm{pH}$ value of 3.7 and 4.0 in concentrate and dilute respectively. In contrast to this the $\mathrm{pH}$ value of the non-effluent stream water was found to be 6.2 which was less acidic than that of other two concentrate and dilute effluents. The total suspended solid of the concentrate and dilute effluents were $32311 \mathrm{mg} / \mathrm{l}$ and $2033 \mathrm{mg} / \mathrm{l}$, respectively, where as that of noneffluent stream water was found to be only $450 \mathrm{mg} / \mathrm{l}$. Dissolve oxygen was found to be $0.36 \mathrm{mg} / \mathrm{l}$ and $2.9 \mathrm{mg} / \mathrm{l}$ in concentrated and dilute effluent, respectively. DO value for non-effluent stream water was analyzed $5.2 \mathrm{mg} / \mathrm{l}$. The N, P, K contents were found to be $465 \mathrm{mg} / \mathrm{l}, 141 \mathrm{mg} / \mathrm{l}, 5440 \mathrm{mg} / \mathrm{l}$, respectively, in concentrate and $335 \mathrm{mg} / \mathrm{l}, 3.9 \mathrm{mg} / \mathrm{l}, 1000 \mathrm{mg} / \mathrm{l}$, respectively, in dilute effluents but the total average content of $\mathrm{N}, \mathrm{P}$, $\mathrm{K}$ for non-effluent stream water was found to be $12.6 \mathrm{mg} / \mathrm{l}, 0.3$ $\mathrm{mg} / \mathrm{l}, 16.8 \mathrm{mg} / \mathrm{l}$, respectively. Biological oxygen demand and chemical oxygen demand values for concentrate effluent were $47520 \mathrm{mg} / \mathrm{land} 58400 \mathrm{mg} / \mathrm{l}$, respectively, and that of dilute effluent were $15450 \mathrm{mg} / \mathrm{l}$ and $32100 \mathrm{mg} / \mathrm{l}$, respectively. BOD and COD values of non-effluent stream water were calculated as $105 \mathrm{mg} / \mathrm{l}$ and $152 \mathrm{mg} / \mathrm{l}$, respectively.

The Iron (Fe) content was detected $115 \mathrm{mg} / \mathrm{l}$ and $102.4 \mathrm{mg} / \mathrm{l}$ in concentrate and dilute effluent, respectively. But in case of non-effluent water it was found to be $4.7 \mathrm{mg} / \mathrm{l}$. The Manganese $(\mathrm{Mn})$ content of concentrate and dilute effluent was analyzed to be $6.4 \mathrm{mg} /$ land $5.7 \mathrm{mg} / \mathrm{l}$, respectively where as in noneffluent stream water it was found to be $0.6 \mathrm{mg} / \mathrm{l}$. The Lead (Pb) content was found to be $0.56 \mathrm{mg} / \mathrm{l}$ and $0.26 \mathrm{mg} / \mathrm{l}$ in concentrate and dilute effluent, respectively where as in noneffluent stream water it was $0.01 \mathrm{mg} / \mathrm{l}$. The Copper $(\mathrm{Cu})$ content was analyzed to be $0.14 \mathrm{mg} / \mathrm{l}$ and $0.05 \mathrm{mg} / \mathrm{l}$ in concentrate and dilute effluent, respectively, where as it was $0.04 \mathrm{mg} / \mathrm{l}$ in non-effluent water. Similarly, Zinc (Zn) content in concentrate and dilute effluent were found to be $3.1 \mathrm{mg} / \mathrm{l}$ and $1.21 \mathrm{mg} / \mathrm{l}$ respectively, where as non-effluent stream water it was found to be $0.06 \mathrm{mg} / \mathrm{l}$.

\section{Effect of the Karnali Distillery Effluent on Soil Characters}

The average $\mathrm{pH}$ value of soil irrigated with effluent mixed stream water was slightly lower (6.4) than that of irrigated with non-effluent stream water was (7.2). The organic matters content in average was higher with the value of 4.07 percent in the soil irrigated with effluent mixed water than in the soil irrigated non-effluent water was 0.52 percent. Organic matter content of soil irrigated by non-effluent water was less after monsoon where as it was found higher in soil irrigated by effluent mixed stream water after monsoon. The nutrients such as nitrogen, phosphorus and potassium were found higher in soil irrigated with effluent mixed water. Potassium was analyzed in sufficient amount in both soil i.e. irrigated by effluent mixed and non-effluent stream water. Nitrogen content in average was found slightly higher in the soil irrigated with effluent mixed water $(0.17 \%)$ than in soil irrigated by non-effluent mixed water (0.1\%). Except $\mathrm{Zn}$ all the analyzed heavy metals ( $\mathrm{Fe}, \mathrm{Pb}, \mathrm{Mn}, \mathrm{Cd}$ and $\mathrm{Cu}$ ) content were found to be higher in 


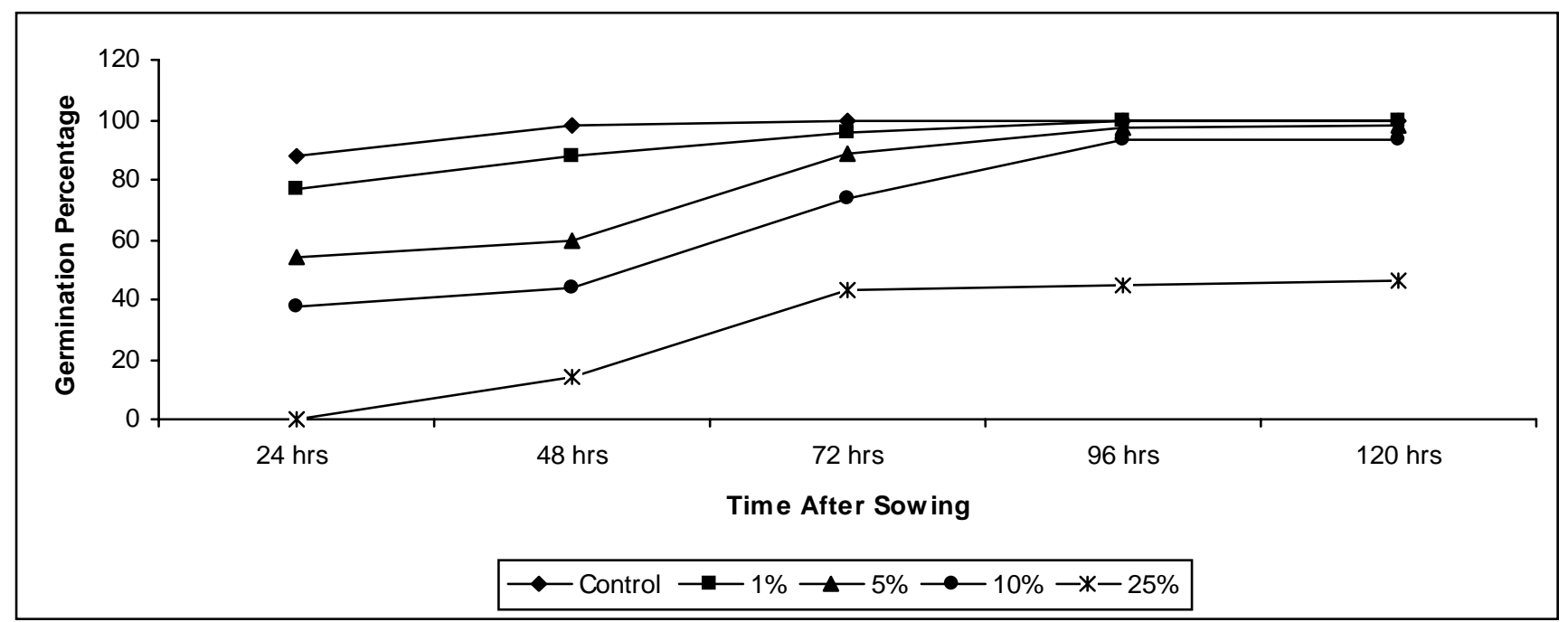

Fig. 1: Effect of effluent on seed germination of Oryza sativa. Variance ratio at 5\% level Fcal=14.64 and 39.59 (Ftab=3.01 and 3.24) for hours of sowing and treatment concentration at d. f. (4, 16 and 5, 16).

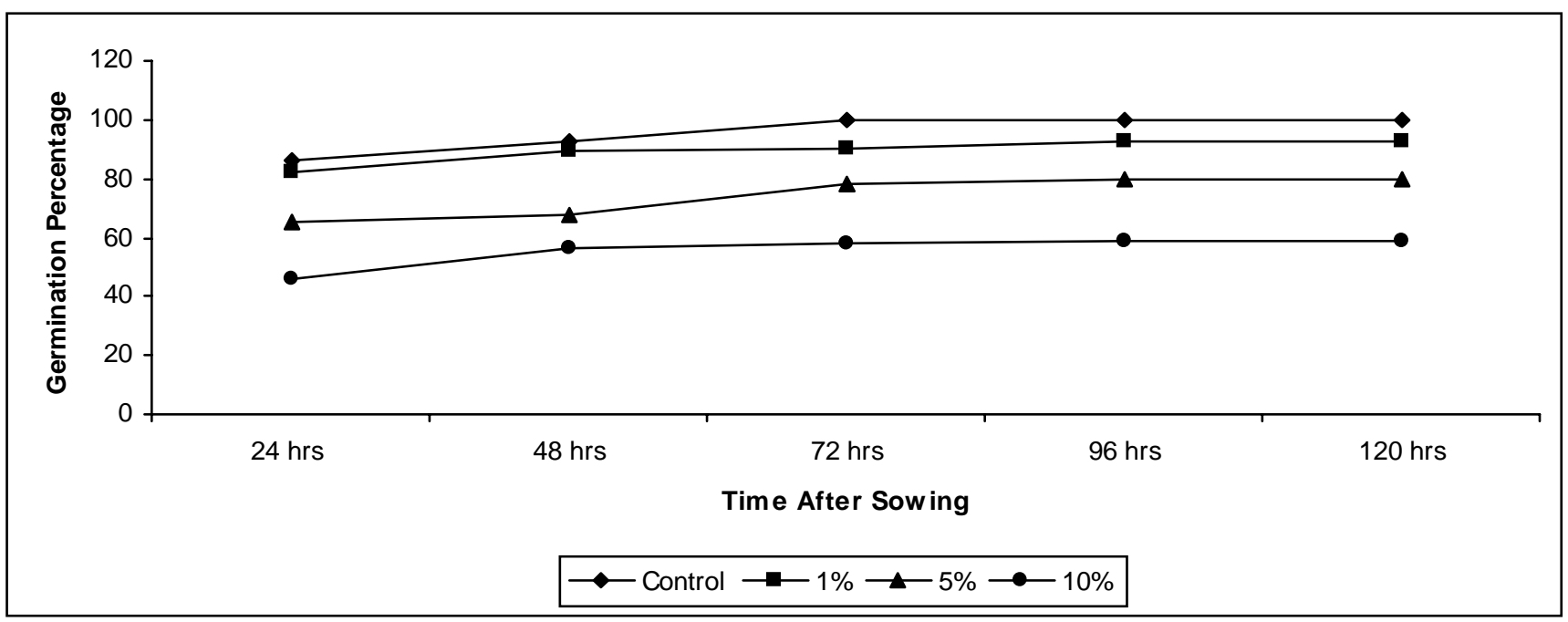

Fig. 2: Effect of effluent of seed germination of Triticum aestivum. Variance ratio at 5\% level Fcal=14.87 and 205.89(Ftab=3.26 and 3.49) for hours of sowing and treatment concentration at d. f. $(4,12)$ and $(3,12)$ respectively.

the soil irrigated with effluent mixed water than in the soil irrigated with non-effluent water.

\section{Seed Germination and Seedling Growth}

Distillery effluent in different concentrations (1\%, 5\%, 10\% and $25 \%$ ) affect seed germination of paddy and wheat, (Fig 1, 2). Different concentrations of effluent bring significant change in the rate of seed germination. At lower concentration $(1 \%, 5 \%)$ germinations was found to be nearly equal to the control but at higher concentration (10\%, $25 \%$ in case of paddy and 5\%, 10\% in case of wheat) imposed inhibitory effect. Seed could not germinate above the concentration level of 25 percent.

Seedling growth of two test crops was significantly affected by the distillery effluent (Fig 3, 4). Lower concentration (1\%, 5\%) slightly enhanced the shoot growth of paddy. In case of wheat, shoot growth enhanced at 1 percent only where as higher concentration $(10 \%, 25 \%)$ had inhibitory effect. The effect was more pronounced at 25 percent concentration. Comparatively the root growth was more affected than that of shoot.
Lower concentrations of effluent (1\% and 5\%) increased the fresh weight of seedling in case of paddy where as the fresh weight of wheat was found decreased with the increase of effluent concentration (Fig 5). Effect of different concentration of effluent on dry weight of shoot and root of test crops was found statistically significant at $\mathrm{P}=0.05$. The dry weight of rice seedling decreased at higher concentration but comparatively it was higher in case of 1 percent and 5 percent effluent concentration similar to fresh weight where as in case of wheat, the dry weight has decreased with the increase of concentration except at 1 percent effluent concentration which slightly enhanced the dry weight of wheat seedling unlike to its fresh weight (Fig 6).

\section{Crop Yield}

The data obtained through interview with local people revealed that the average productivity of rice and wheat on the land irrigated with non-effluent stream water (Site A) was found to be around $4,810 \mathrm{~kg} / \mathrm{ha}$ and $837 \mathrm{~kg} / \mathrm{ha}$, respectively, where as on the land irrigated with effluent mixed water (Site B) was 


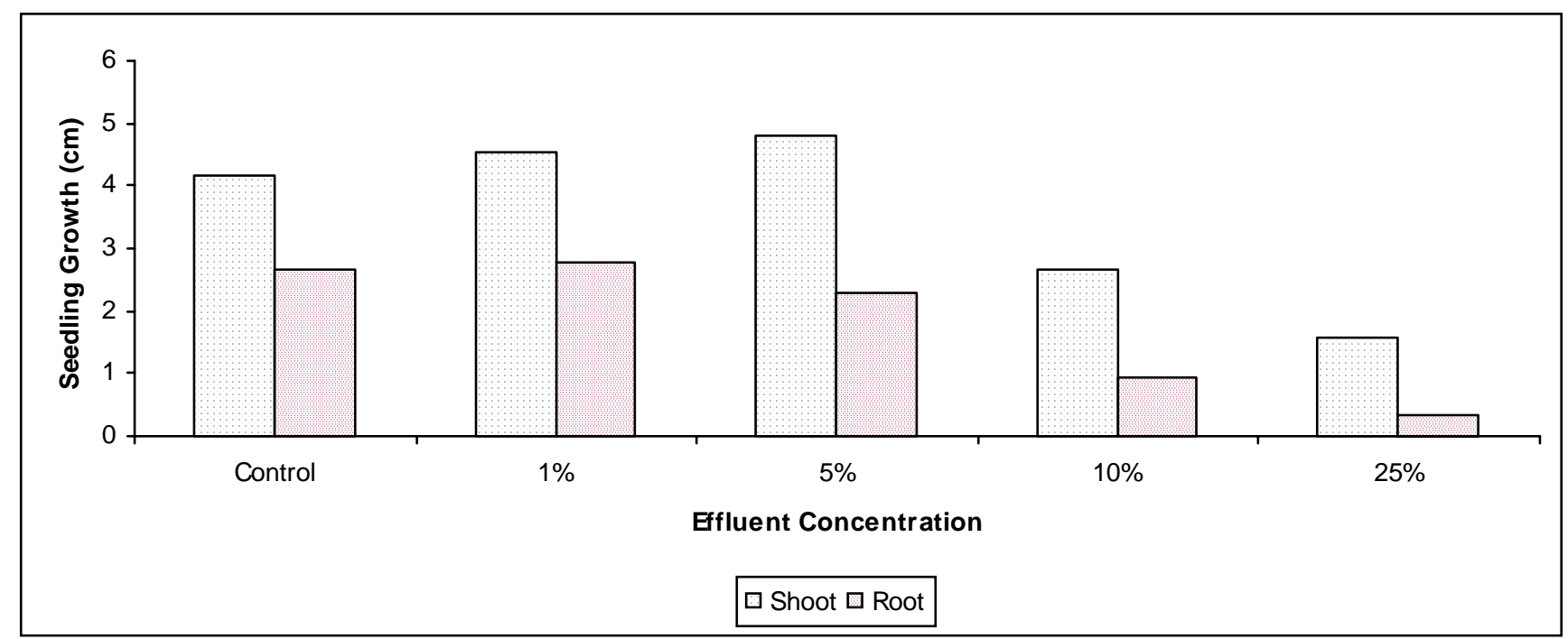

Fig3: Effect of effluent on seedling growth of Oryza sativa. Variance ratio at 5\% level, Fcal=9.51, 6.96 (Ftab=3.84, 4.46) and Fcal 7.24, 5.10 $(\mathrm{Ftab}=3.84,4.46)$ for days of sowing and treatment concentration at d.f. $(4,8),(2,8)$ for shoot and roots respectively.

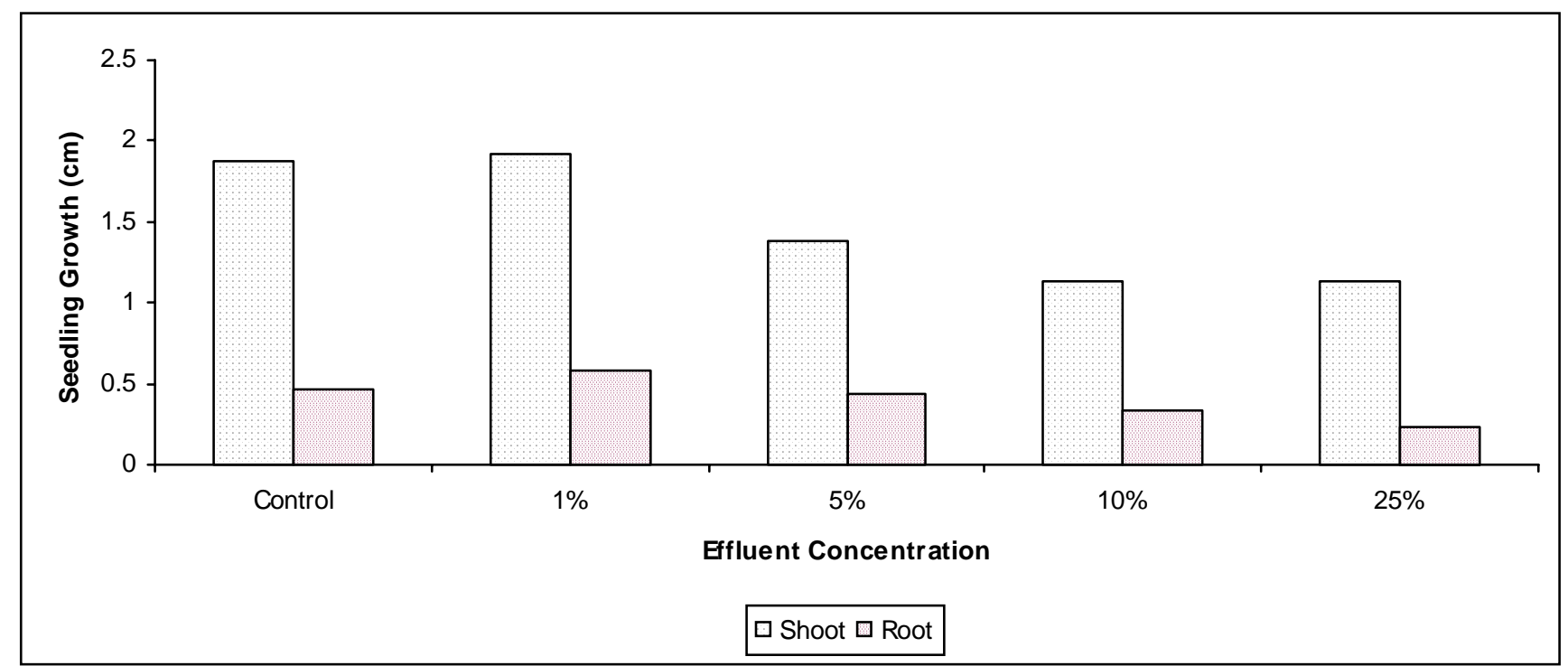

Fig. 4: Effect of effluent on seedling growth of Triticum aestivum variance ratio at 5\% level, Fcal=23.23, 19.61 (Ftab=4.76, 5.14) and Fcal= 4.83, 6.06 (Ftab=4.76, 5.14) for days of sowing and treatment concentration at d.f. $(3,6)(2,6)$ for shoots and roots respectively.

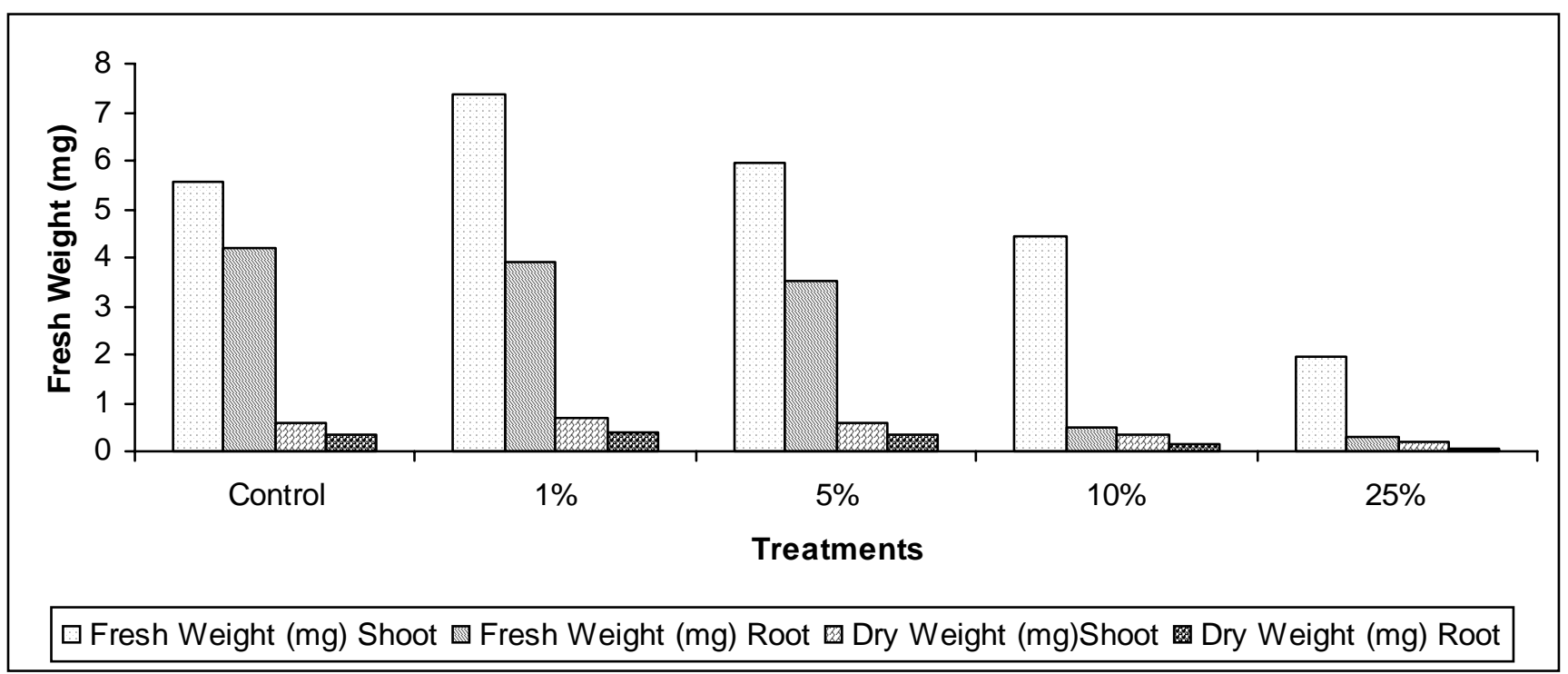

Fig 5: Effect of effluent on fresh and dry weight of Oryza sativa seedling, variance ratio at 5\% level, Fcal=12.03 (Ftab=5.32) at d. f. (1, 8) and Fcal=4. $34($ Ftab=5. 32) at d. f. $(1,3)$ respectively with respect to effluent concentration. 


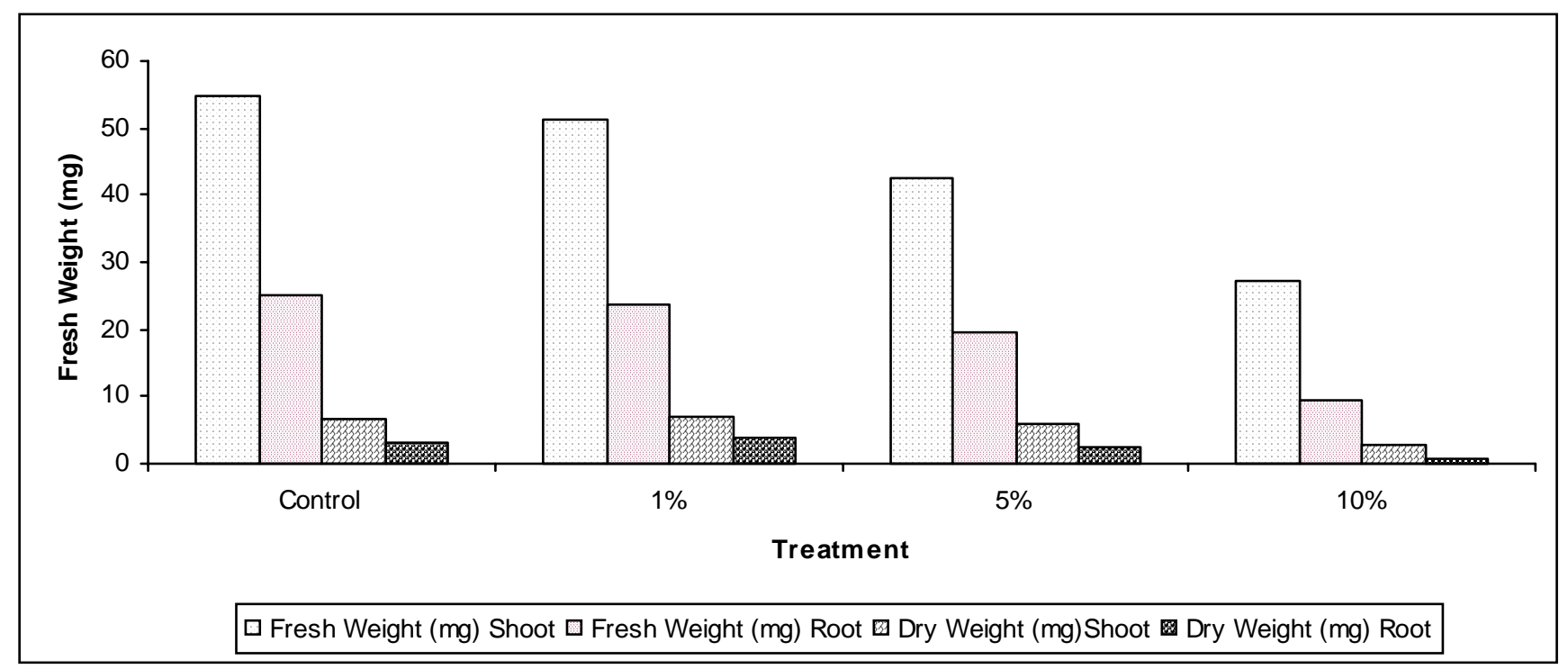

Fig 6: Effect of effluent on fresh and dry weight of Triticum aestivum seedling, variance ratio at $5 \%$ level, Fcal= $7.74($ Ftab=5.99) at d. f. $(1,6)$ and Fcal=7. 88 (Ftab=5. 99) at d. f. $(1,6)$ respectively with respect to effluent concentration.

found to be 2,477kg/ha and 688.8kg/ha, respectively (Fig 7).

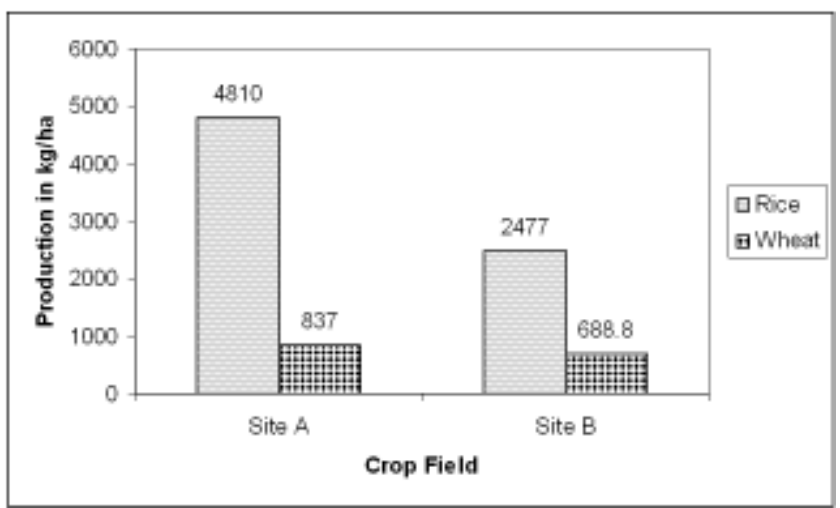

Fig. 7: Productivity of the crop fields irrigated by effluent non-mixed water (Site A) and effluent mixed water (Site B).

The temperature of the distillery effluent was recorded as $105^{\circ} \mathrm{C}$ which was relatively higher than that of dilute and noneffluent stream water which were recorded as $36^{\circ} \mathrm{C}$ and $30^{\circ} \mathrm{C}$, respectively. Neupane (2003) found the temperature of the distillery effluent of Lumbini sugar factory to be $102^{\circ} \mathrm{C}$ which was close to the present study. An increase in water temperature decreases the oxygen saturation percentage and at the same time it accelerates the lowering of DO levels. An increase in temperature also increases the toxicity of some chemical pollutants (Rao, 1991).

In the present study $\mathrm{pH}$ of the effluent was found highly acidic with $\mathrm{pH}$ value 3.7 and 4.4 in concentrate and dilute effluent, respectively. The $\mathrm{pH}$ recorded were very low than the tolerance limit fixed for any industrial effluent (NS, 1990) or any fermentation industry (NS, 1995), where as in noneffluent water it was slightly acidic. Neupane (2003) found the $\mathrm{pH}$ in distillery effluents of sugar mills to be 4.7 and 4.3 respectively which were close to that of present study. Sah et al. (2000) found pH of Shree distillery to be 5.1 which was relatively less acidic than in the present report. The low $\mathrm{pH}$ of the distillery effluent might be due to the presence of higher concentration of organic acids such as $\mathrm{CH}_{3} \mathrm{COOH}$.
The total suspended solid (TSS) of the concentrate and dilute effluent were found extremely higher than maximum limit fixed for a fermentation industry (NS, 1995) or any industrial effluent (NS, 1990). The high amount of TSS in the effluent indicated presence of high organic suspended solids. Devkota (1997) also analyzed the TSS of distillery effluents to be 11,230 $\mathrm{mg} / \mathrm{l}$ which was similar to that of present study where as the TSS of non-effluent stream water was found to be less than tolerance limit of any industrial effluent. The DO values of concentrate and dilute effluents in the present study were analyzed extremely low with the values of $0.36 \mathrm{mg} / \mathrm{l}$ and 2.9 $\mathrm{mg} / \mathrm{l}$, respectively, where as it was little bit high in non-effluent stream water. Low DO might be due to presence of high amount of oxygen demanding organic wastes. This result was very near to the Gewali et al. (1994) in carpet and dying effluent and Sharma and Rijal (1988) in carpet effluent.

$\mathrm{N}, \mathrm{P}, \mathrm{K}$ content in concentrate and dilute effluent were found much higher than non-effluent stream water. Among these three major plants nutrient $\mathrm{K}$ was found in highest amount followed by N and P. Mahimairaja et al. (2004) also reported the similar result.

BOD and COD in the effluent were found much higher in case of dilute effluent in comparison to non-effluent stream water. They were found to be higher than the tolerance limit fixed for any fermentation industry or any other industrial effluent (NS 1990, 1995). High BOD and COD might be due to presence of high oxidizable organic matter and rapid consumption of dissolved inorganic materials. Sah et al. (2000) and Devkota (1997) analyzed BOD and COD of distillery industry effluent which were found less than the present study but still higher than the tolerance limit.

In case of heavy metals, except $\mathrm{Zn}$ and Cu other heavy metals i.e. $\mathrm{Mn}, \mathrm{Fe}, \mathrm{Pb}$ and $\mathrm{Cd}$ were found much higher than the maximum permissible value fixed for industrial effluent (IS 1974, NS 1990). Fe content in concentrate and dilute effluent were found to be $115 \mathrm{mg} / \mathrm{l}$ and $102.4 \mathrm{mg} / \mathrm{l}$, respectively. Abnormal level of Fe adversely effects the growth and causes other 
physiological disorder in paddy and other crop plants (Woolhouse, 1983). Likewise, high content of $\mathrm{Pb}$ inhibits the root growth and seed germination of source vegetable crops (Pokhrel et al. 2001). Similarly higher concentration of Cd inhibits uptake of $\mathrm{P}$ and K (Matsuo et al., 1995). Sah et al. (2000) analyzed the $\mathrm{Fe}, \mathrm{Mn}$ and $\mathrm{Pb}$ of Shree distillery and found to be $57.50 \mathrm{mg} / \mathrm{l}, 68.05 \mathrm{mg} / \mathrm{l}$ and $0.28 \mathrm{mg} / \mathrm{l}$, respectively, which were higher than tolerance limit and similar to present study.

The soil irrigated with effluent mixed water was found slightly acidic with $\mathrm{pH}$ value 6.4 which was within the tolerable range for the soil (Sah et al., 2000) where as the soil irrigated by noneffluent water was found to be slightly basic with $\mathrm{pH}$ value 7.2. Decrease in the $\mathrm{pH}$ of distillery effluent mixed irrigated soil may attribute to the acidic nature of the spentwash and the release of organic acids during the decomposition.

The total average organic matter content in the soil irrigated with effluent mixed water was found to be higher than the soil irrigated with non-effluent water. The high amount of organic matter in soil irrigated with effluent mixed water might be due to the high organic nature of the effluent. Acharya (2001) also found the organic content in the soil irrigated with brewery industry effluent to be higher than in the soil irrigated with uncontaminated water.

The average values of $\mathrm{N}, \mathrm{P}$ and $\mathrm{K}$ in the soil irrigated with effluent mixed water were found to be higher than in the soil irrigated with non-effluent stream water. The high amount of $\mathrm{N}, \mathrm{P}$ and $\mathrm{K}$ in the soil was due to irrigation with $\mathrm{N}, \mathrm{P}$, and $\mathrm{K}$ rich distillery effluent. Neupane (2003) analyzed the N, P and K content in soil irrigated with sugar industry effluent to be 0.033 percent, $126 \mathrm{~kg} / \mathrm{ha}$ and $191 \mathrm{~kg} / \mathrm{ha}$, respectively which were similar to present study. The soil amendment with distillery effluent for wheat and paddy cultivations affects the increase organic carbon and available potassium content of post harvest soils (Pathak et al., 1999).

Except Zn, the concentration of heavy metals Fe, Mn, Cu, Pb and $\mathrm{Cd}$ were found higher amount in the soil irrigated with effluent mixed water than in the soil irrigated with non-effluent water. Similar was the result by Sah et al. (2000) in the concentration of micronutrients ( $\mathrm{Zn}, \mathrm{Fe}, \mathrm{Mn}$ and $\mathrm{Cu}$ ) in the soil irrigated with paper industry effluent.

The germination of test seeds was observed to be similar to control in lower concentrations (1\% for wheat and $1 \%, 5 \%$ for rice). But in higher concentration (10\% for wheat and $25 \%$ for rice) germination was completely inhibited. Similar result was found by Sahai et al. (1983) in case of rice (Oryza sativa). The inhibition effect of the germinations was more prominent on the seed of wheat (Triticum aestivum) than in rice (Oryza sativa) which showed that the effect of distillery effluent was crop specific. This result was supported by Ramana et al. (2002). Extreme range of $\mathrm{pH}$ value might be the main reason for the greater toxic effect on the seed germination, at higher concentration (Chaudhary, 1983 and Thukural and Kaur 1987). The effluent had both stimulatory and inhibitory effects on growth of seedlings as compared to control. In case of rice (Oryza sativa) it showed stimulatory effect at lower concentrations (1\% and 5\%) but inhibitory effect was found at higher concentration (25\%) where as in case of wheat, it had inhibitory effect at all concentration (except 1\%) as compared to control. Chandra et al. (2004) also found the effect of distillery effluent on the growth of Phaseolus aureus and found stimulatory effect at lower concentration (1\%-5\%) and inhibitory effect (15\%-20\%) which was similar to present study.

In the present study root growth of both test crops were found more affected than shoot growth. Sahai et al. (1983) reported that distillery effluent contained excessive amount of dissolved materials (cations and anions) which might be injurious to germination and seedling growth and also observed that root growth was more adversely affected than shoot growth which supported the result of present study. It was observed that at lower concentrations (1\% and 5\% in case of rice) the seedling growth was stimulated according to which fresh weight and dry weight of seedlings was also found more in these treatments. But in case of wheat, fresh weight and dry weight of seedlings decreased with the increase of concentrations except of dry weight at 1 percentage concentration which showed little increase. Such types of effect of effluents on fresh and dry weight of seedling was due to desired level of nutrient in diluted condition but makes toxic level at high concentration. Similar result of increase or decrease of dry weight in case of different Brassica crops was obtained by Pokhrel (2000) with the treatment of different concentration of $\mathrm{Pb}$ and $\mathrm{Cr}$.

It was observed that the average annual production rate of both rice and wheat of the land irrigated by non-effluent stream water was $2719 \mathrm{~kg} / \mathrm{ha}$ in average where as that of the land irrigated with effluent mixed water was $1583 \mathrm{~kg} / \mathrm{ha}$ which showed $40 \%$ less production. The effluent might have decreased the productivity of the soil. Farmers had also complained about the rapid growth of unnecessary weeds and insects in the crop field which decrease the productivity.

\section{Environmental Justice}

Karnali distillery is located near the human settlements and large agriculture land. Since more than twenty years the factory has been frequently discharging its effluent in the Kiran khola (a rivulet) near by the factory which is a main source of irrigation for marginalized local farmers. Local farmer have also been facing the problems of abortion and death of their cattle due to consumption of effluent mixed water. Similarly hazardous awful smell of the effluent in the adjoining area of the industry has been noticed as other issues of environmental injustice caused by Karnali distillery industry. Present study revealed that BOD, COD and TSS of discharged effluent were extremely higher than tolerance limit (NS, 1990). Likewise some heavy metals ( $\mathrm{Pb}, \mathrm{Cd}$, and $\mathrm{Fe}$ ) and $\mathrm{pH}$ were also found very high. It has resulted in environmental hazards and decreased the cropland productivity which has become serious issue of environmental injustice to local farmers.

The farmers have to bear about 40 percent annual loss in crop productivity. This study verified the experience of the local farmers on the trend of decrease in productivity by interfering fertility of soil. Anonymous (2006) also reported that cropland of four village development committees (VDCs) i.e. 
Khajura Khurd, Bageshwari, Sitapur and Radhapur have decreased the productivity due to the effect of Karnali distillery effluent and farmers are getting trouble in their occupation which revealed environmental injustice. To minimize the existing injustice to the local farmers and to guarantee the constitutional right to clean environment, the factory owner must compensate to local farmers and install measures to treat or minimize the load of pollutants in the effluent before it is discharged to the river.

\section{CONCLUSION}

The findings of this study concluded that local people and farmers are facing injustice in term of agricultural production, compensation and environmental hazards due to Karnali Distillery industry.

\section{REFERENCE}

Acharya, I. 2001. Effect of brewery industrial effluents on some agricultural crops and soil. M.Sc. Dissertation, Central Department of Botany, Tribhuvan University, Kirtipur, Kathmandu. .

Anonymous. 2006. "Distilleryko phoharle char gabisa prabhabit” (in Nepali). Nepali Express (National Daily) 1 July, 2006.

APHA. 1998. Standard methods for the examination of water and waste water. American Public Health Association (APHA), Washington DC, 20th Edition.

Bajwa. M.S, Arura, B.R, Chahal, D.S., Kausal, B.D., Chhibba, I.M. and Arora, C.L. 1997. Practical manual. Soil Fertility (Soils 201) Ludhiana Chapter India, Socio and Soil Science Department of Soil, Punjab Agriculture University, Ludhiana.

Belbase, N and Thapa, L.B. 2007. "Environmental Justice and Rural Communities: Nepal” In: Environmental justice and rural communities: Studies from India and Nepal (ed.) Moore P. and Pastakia F. IUCN Bangkok, Thailand and Gland, Switzerland , pp 64-113.

Charndra, R., Kumar, K. and Singh, J. 2004. Impact of anaerobically treated and untreated (raw) distillery effluent irrigation on soil microflora growth, total chlorophyll and protein contents of Phaseolus aureus L. Journal of Environmental Biology 24(4):381-385.

Chaudhary, R.P. 1983. Effect of Bansbari tannery and shoe factory effluent on seed germination and seedling growth of cereal crops. (Project Report). Institute of Science and Technology. Tribhuvan University, Kirtipur, Kathmandu, Nepal. .

Devkota, S.R. 1997. Industrial wastes survey in Nepal. Industrial Pollution Control Management Project, United Nation Development Project /United Nations Industrial Development Organization/ Ministry of Industry, Kathmandu.

Gewali, M.B., Amatya, R., Rai, R., Awale, S. and Schaumberg, G.D. 1994. Chemical analysis of industrial waste water from Kathmandu valley. Journal of Nepal Chemical Society Vol. 12.

Ghimire, S.K. 1994. Evaluation of industrial effluent toxicity in seed germination and seedling growth of some vegetables. M.Sc. Dissertation, Central Department of Botany, Tribhuvan University, Kirtipur, Kathmandu.

IS. 1974. Tolerance limits for industrial effluents discharged into inland surface waters. Indian Standards (IS), New Delhi, India.

Mahimairaja, S. and Bolan, N.S. 2004. Problems and prospects of agricultural use of distillery spent wash in India. Super Soil, Third edition, Australian New Zealand Soil Conference. University of Sydney, Australia. Available: http://www.regional.org.au/ay/asssil.

Matsuo, T., Kumazawa, K., Ishii, R., Ishihara, K. and Hirara, H. 1995. The science of the rice plant physiology. Food and Agriculture Research Centre, Tokyo, Japan.
Nagraj, C. M. and Kumar, A. 2006. Distillery waste water treatment and disposal, International Journal of Environmental Science and Technology 3(2).

Neupane, R.P. 2003. Effect of industrial effluents on agricultural crops and soil. M.Sc. Dissertation, Central Department of Botany, Tribhuvan University, Kirtipur, Kathmandu.

NS. 1990. Tolerance limits for industrial effluents discharged into inland surface water. Paper No. NS 229-2047 and Paper No. NS 229-2054. Nepal Bureau of Standards and Meteorology/HMG Nepal, Ministry of Industry, Kathmandu.

N.S. 1995. Tolerance limits for effluent discharged into inland source water. Part: 3 Fermentation industries Nepal Standard (NS), Ministry of Industry. Nepal Bureau of Standard.

Pathak, H., Joshi, H.C., Chaudhary, A., Chandhary, R., Kalra, N. and Dwiwedi, M.K. 1999. Soil amendment with distillery effluent for wheat and rice cultivation. Water, Air and Soil Pollution 113 (1-4): 133-140.

Pokharel, A. and Lekhak, H.D. 2001. Effect of lead on germination and seedling growth of some vegetable crops. In: Environment and agriculture: Biodiversity, agriculture and pollution in South Asia (eds.) Jha, P.K., S.R. Baral, S.B. Karmacharya, H.D. Lekhak, P. Lacoul and C.B. Baniya. Ecological Society (ECOS), Nepal, pp. 519-524.

Pokharel, B., Niroula, B. and Rai, S.K. 2000. Study of toxicity of some industrial effluents on root growth of Allium cepa. In: Third national conference of science and technology. Proceedings (Volume II). Royal Nepal Academy of Science and Technology (RONAST). pp 1151-1154.

Ramana S., Biswas, A.K., Kunda, S., Saha, J.K. and Yadava, R.B. 2002. Effect of distillery effluent on seed germination in some vegetable crops. Bioresource Technology 82 (3): 273-275.

Rao, C.S. 1991. Environmental pollution control engineering. Wiley Eastern Limited and New Age International Limited, India.

Sah, S.K., Sah, J.P. and Lance, V.A. 2000. Industrial effluents and their use in agriculture along the Narayani River, Nawalparasi, Nepal. In: Environment and agriculture: At the cross road of the new millennium (eds.) Jha, P.K., S.B. Karmacharya, S.R. Baral and P. Lacoul. Ecological Society (ECOS), Nepal, pp. 456-466.

Sahai, R.S. Jabeen and Saxena, P.K. 1983. Effect of distillery waste on seed germination, seedling growth and pigment content of rice. Indian Journals of Ecology 10 (1): 7-10.

Sharma, A.P. and Rijal, A. 1988. Impact of industrial effluent on pollution of river and adjoining land. Report Submitted to Nepal National Committee for Man and Biosphere, Kathmandu.

Singh, J., Kansal, B.D. and Pansesear, R.S. 1985. Chemical composition of waste water of Amritsar city. Indian Journal of Ecology 12 (1): 12-16.

Street H.E. and Opik, H. 1976. The physiology of flowering plants. Edward Arnold publishers Ltd. Hill Street, London.

Thapa, V. 1994. Effect of industrial effluent on seed germination and seedling growth in some cereals. M.Sc. Dissertation, Central Department of Botany, Tribhuvan University, Kirtipur, Kathmandu.

Thukural, A.K. and Kaur, P. 1987. Effect of some trace elements of polluted water of the germination of Cymopsis tetragonoloba Toub. Indian Journal of Ecology 14 (2): 185-188.

Trivedy, R. K. and Goel, P.K. 1986. Chemical and biological methods for water pollution studies. Environmental Publications, Karad, India.

U.S./EPA, 2000. Guidance for incorporating environmental concerns. In: Dumping in Dixie race class and environmental quality (ed.) Robert Bullard. Environment Protection Agency's compliance analysis (Washington D.C.EP, 1998) in West View Press USA, 138 pp.

Woolhouse, H.W. 1983. Toxicity and tolerance in the responses of plants to metal. In: Encyclopaedia of plant physiology (eds.) Lang. O.L., P.S. Nobel, C.B. Osmond and H. Zioegler. New Series 12: 245-300. 